Archiv für die gesamte Virusforschung 36, 43-52 (1972)

(C) by Springer-Verlag 1972

\title{
Clinical Reactivity and Immunogenicity of Hemagglutinin Influenza Vaccine
}

I. Clinical Reactions, Hemagglutination-Inhibiting and Strain and Type-Specific Complement-Fixing Antibody Responses in Subjects Aged $3-6,16-17$ and $27-50$ Years

By

Hana Závadová, Vladimír Vonka, Ervin Adam, Eva Domorázková, and Fred M. Davenport ${ }^{1}$

Department of Experimental Virology and Clinical and Epidemiology Department, Institute of Sera and Vaccines, Prague, Czechoslovakia

Received April 5, 1971

\section{Summary}

Subjects aged $3-6,16-17$ and $27-50$ years were vaccinated with one dose of hemagglutinin influenza virus vaccine. Clinical reactions, hemagglutinationinhibiting (HI) and strain- and type-specific complement-fixing (CF-V and CF-S) antibodies were determined in sera taken before and four weeks after vaccine administration. The results indicated that the reactogenicity of the vaccine was very low. The HI antibody response differed with the age of the vaccinees, apparently being conditioned by prior exposure to the various influenza virus subtypes. The results of CF tests using strain-specific $V$ antigens corresponded in general with HI tests, with two marked exceptions. In the youngest group nearly half of the subjects developed CF antibody to V-Swine, while all of them remained without antibody detectable in the HI test. However, when V antigen was used instead of intact virus as hemagglutinin, the post-vaccination sera of these subjects also reacted positively in the HI test. Secondly, a number of prevaccination sera from persons aged $27-50$ years possessed $\mathrm{CF}$ antibody to A/PR 8 in the absence of homologous HI antibody. Among these subjects the antibody response to both $A / P R 8$ and Swine was more marked in the CF test than in the HI test. After vaccine administration most of the subjects developed antibody or responded by an antibody increase to the $\mathrm{S}$ antigens of both influenza $\mathrm{A}$ and B. No significant differences were found after intradermal $(0.1 \mathrm{ml})$ and subcutaneous $(0.5 \mathrm{ml})$ administration of one dose of vaccine.

${ }^{1}$ Department of Epidemiology, School of Public Health, University of Michigan, Ann Arbor, Michigan, U.S.A. 


\section{Introduction}

In the last several years a new concept of preparing influenza vaccine has been developed (DavenporT et al., 1964). The new type of vaccine only contains a fraction of the virion, namely the hemagglutinin, which is released after treating the virion with lipid solvents. The first experiences with this new type of vaccine have been encouraging. It has been shown by DaveNPoRT et al. (1964) and BRANDoN et al. (1967) that the reactogenicity of ether-treated virus preparations for human beings is very low, while their antigenicity - as measured by the development of hemagglutination-inhibition (HI) and virus-neutralization antibodies - is retained.

A number of intriguing questions associated with the use of the hemagglutinin influenza vaccines remain to be solved. Among these are the reactogenicity of the preparations in different age groups after single and repeated administration and the levels and nature of the antibodies induced.

To find an answer to these questions, a collaborative study of a polyvalent hemagglutinin vaccine has been initiated by the laboratories indicated above. The first part of the results is summarized in this paper.

\section{Materials and Methods}

\subsection{Vaccine}

The experimental vaccine lot was prepared by Parke, Davis and Co., by the procedure described by BRANDon et al., (1967). The vaccine content (per ml) was: A/S wine/ 31: $200 \mathrm{CCA} ; \mathrm{A} / \mathrm{PR} 8 / 34: 200 \mathrm{CCA} ; \mathrm{A}_{1} / \mathrm{AA} / 1 / 57: 100 \mathrm{CCA} ; \mathrm{A}_{2} /$ Taiwan/64: $300 \mathrm{CCA}$; $\mathrm{B} / \mathrm{Lee} / 40: 100 \mathrm{CCA}$, and $\mathrm{B} / \mathrm{Md} / 59: 300 \mathrm{CCA}$.

\subsection{Selection of subjects}

The vaccine was administered to three groups of subjects. The first were children aged 3-6 years living in two semi-closed homes; about half of the children in each community remained unvaccinated. In each institution approximately one half of the vaccinees received the vaccine intradermally $(0.1-\mathrm{ml})$ and the others were injected subcutaneously $(0.5-\mathrm{ml})$. The same procedure was applied to secondary-school students aged 16-17 years attending two different schools. The third group comprised laboratory personnel aged 27-50 years; all of them were vaceinated intradermally. None of the subjects had previously been vaccinated with influenza vaccine. Before vaccination each vaccinee passed a careful physical examination, including measurement of body temperature.

\subsection{Administration of Vaccine}

Standard-type hot-air-sterilized 1-ml syrings and needles for subcutaneous and/or intradermal injections were used to inject one $0.5-\mathrm{ml}$ dose (subcutaneously) or one $0.1-\mathrm{ml}$ dose (intradermally) of vaccine into the deltoid area of the left arm.

\subsection{Evaluation of Reactions}

Local reactions were followed daily during 4 days after vaccination; the indices recorded comprised erythema, edema, infiltration and lymphatic reaction. Erythema size was measured with a transparent flexible ruler. Two perpendicular measurements were made on the largest extension of the reaction, and the arithmetic mean of these values was recorded in $\mathrm{cm}$. Axillary temperature in children aged $3-6$ years was taken twice a day; in the secondary school students the temperature were taken only once daily, but the vaccinees took afternoon temperatures themselves and reported them the next day. All vaccinees were thereafter regularly examined by the physician of the respective institution; follow-up by the study team continued once weekly. Reactions in the group of laboratory personnel were not followed. 


\subsection{Serum Sampling}

Blood samples were taken immediately before and four weeks after the vaccination. Sera were kept at $-30^{\circ} \mathrm{C}$. The following sera were selected for serological investigations: in the age group of 3-6 years 11 serum pairs from subjects inoculated intradermally and 12 from subjects inoculated subcutaneously; in the age group of 16-17 years 12 serum pairs from subjects inoculated intradermally and the same number from those inoculated subcutaneously; in the group of laboratory personnel 13 serum pairs were available.

\subsection{Viruses}

The A/Swine, A/PR 8, $A_{1} / \mathrm{AA}, \mathrm{A}_{2} /$ Taiwan, $\mathrm{B} /$ Lee and $\mathrm{B} / \mathrm{Md}$ viruses originated from the Ann Arbor laboratory. These were the virus lines which had been submitted for vaccine production. In the Prague laboratory in which the serological investigations were performed, they were passed in 10-day-old chick embryos. Intra-allantoically inoculated embryos were incubated for 48 hours at $35^{\circ}$ (A viruses) or $33^{\circ}$ (B viruses) and held overnight at $4^{\circ} \mathrm{C}$. The allantoic-fluid virus was then used for immunizing rabbits and as starting material for preparing $V$ and $S$ antigens.

The MK-16 mutant of the $A_{2}$ /Singapore/57 virus, which was used in immunofluorescence tests, had been isolated after some passages in rhesus monkey kidney cells (VONKA, 1965).

\subsection{Serological Investigations}

All sera were inactivated at $56^{\circ} \mathrm{C}$ for 30 minutes.

\subsubsection{Hemagglutination-Inhibition Test (HIT)}

Sera were treated with trypsin and $\mathrm{M} / 90 \mathrm{KIO}_{4}$ as recommended by DAvENPORT and Minuse (1964). They were diluted $1: 10-1: 320$ in twofold steps. The test was performed as described previously (TučKoví et al., 1968). Control immune sera prepared in rabbits were included in each experiment.

\subsubsection{Complement Fixation Test (CFT)}

The microtechnique used in this laboratory and the preparation of $S$ and $V$ antigens and $A$ and $V$ antisera in guinea pigs were described previously (ZÁVADOVÁ et al., 1967). The $S$ antigens for immunization and serological reactions were prepared from the $\mathrm{A}_{2} /$ Singapore/57 and $\mathrm{B} /$ Praha strains. All the control sera reacted specifically except the $V$-Swine antiserum (homologous titre $1: 320$ ), which reacted with V-PR 8 antigen in the $1: 20$ dilution, and the A-S antiserum (homologous titre $1: 160$ ), which reacted with the V.Swine antigen at the $1: 5$ dilution level. All sera were diluted from $1: 5$ to $1: 160$ in twofold steps. When calculating geometric mean titers (GMT), sera negative in HIT in the dilution $1: 10$ were considered positive in the dilution $1: 5$. Sera negative in CFR in the dilution $1: 5$ were considered positive in the $1: 2.5$ dilution.

\subsection{Immunofluorescence Tests}

The technique was the same as in previous experiments (ZÁvadoví et al., 1968). Rhesus monkey-kidney cells grown on cover-slips were infected with the $A_{2} /$ Singapore MK-16 virus at an input multiplicity of $25 \mathrm{EID}_{50}$ per cell and incubated at $37^{\circ} \mathrm{C}$ for 6 hours. They were then fixed, reacted with sera diluted $1: 2$ and stained with pig anti-human globulin labelled with FITC.

\section{Results}

\subsection{Clinical Studies}

The development of erythema of $\geqq 1 \mathrm{~cm}$ in children aged $3-6$ years in the course of three days following vaccination is shown in Table 1. After subcutaneous injection no difference in the frequency of these local reaction after 24 and 48 hours was observed; however, an increasing trend in size was noted. Following intradermal injection, local reactions developed in 48 hours; their frequency 
increased from $19 \%$ after 24 hours to $34 \%$ after 48 hours. Also the mean size of the erythema increased somewhat during this period. Local reactions of $\geqq 4 \mathrm{~cm}$ were found in $28 \%$ of subcutaneously and only $6 \%$ of intradermally vaccinated children, respectively. This difference is significant $(\mathrm{P}<0.05)$.

Table 1. Development of erythema ( $\geqq 1 \mathrm{~cm})$ in the Course of Three Days Following Vaccination of Ohildren Aged 3-6 Years

\begin{tabular}{|c|c|c|c|c|c|c|c|}
\hline \multirow{2}{*}{$\begin{array}{l}\text { Time } \\
\text { after } \\
\text { vaccina- } \\
\text { tion } \\
\text { (hours) }\end{array}$} & \multicolumn{4}{|c|}{$0.5 \mathrm{ml}$ vaccine subcutaneously } & \multicolumn{3}{|c|}{$0.1 \mathrm{ml}$ raccine intradermally } \\
\hline & $\begin{array}{l}\text { Number of } \\
\text { vaccinees }\end{array}$ & $\begin{array}{l}\text { Oc } \\
\text { of }\end{array}$ & $\begin{array}{l}\text { rrence } \\
\text { ythema }\end{array}$ & $\begin{array}{l}\text { Mean size of } \\
\text { erythema } \\
\text { (cm) }\end{array}$ & $\begin{array}{l}\text { Number of } \\
\text { vaccinees }\end{array}$ & $\begin{array}{l}\text { Occurrence } \\
\text { of erythema }\end{array}$ & $\begin{array}{l}\text { Mean size of } \\
\text { erythema } \\
\text { (em) }\end{array}$ \\
\hline 24 & 33 & 10 & $(30)^{1}$ & 3.0 & 32 & $(19)$ & 1.9 \\
\hline 48 & 33 & 10 & $(30)$ & 3.7 & 32 & $(34)$ & 2.5 \\
\hline 72 & 33 & 2 & (6) & 3.0 & 32 & (6) & 3.0 \\
\hline
\end{tabular}

1 The numbers in parantheses indicate percent of group developing erythema.

Table 2. Increase of Temperature in the First 4 Days Following Vaccination in Children Aged 3-6 Years

\begin{tabular}{|c|c|c|c|c|c|}
\hline \multirow{3}{*}{$\begin{array}{l}\text { Time after } \\
\text { vaccination } \\
\text { (hours) }\end{array}$} & \multirow[t]{3}{*}{$\begin{array}{l}\text { Temperature } \\
\left({ }^{\circ} \mathrm{C}\right)\end{array}$} & \multicolumn{2}{|c|}{$\begin{array}{l}0.5 \mathrm{ml} \text { vaccine } \\
\text { subcutaneously }\end{array}$} & \multicolumn{2}{|c|}{$\begin{array}{l}0.1 \mathrm{ml} \text { vaccine } \\
\text { intradermally }\end{array}$} \\
\hline & & \multicolumn{2}{|l|}{$33^{1}$} & \multicolumn{2}{|l|}{32} \\
\hline & & morning & evening & morning & evening \\
\hline \multirow[t]{2}{*}{24} & $37.0-37.9$ & - & - & - & 2 \\
\hline & -38.0 & - & - & - & - \\
\hline \multirow[t]{2}{*}{48} & $37.0-37.9$ & $(12)$ & $2(6)^{3}$ & - & $1^{2}$ \\
\hline & -38.0 & - & - & - & - \\
\hline \multirow[t]{2}{*}{72} & $37.0-37.9$ & $1 \quad(3)$ & $1 \quad(3)$ & 4 (12) & - \\
\hline & -38.0 & - & - & - & - \\
\hline 96 & $37.0-37.9$ & $2(6)$ & $1 \quad(3)$ & $1 \quad(3)$ & - \\
\hline
\end{tabular}

1 Number of Children in group

2 One child only had repeatedly elevated temperature

3 Numbers in parentheses: mean percent.

Table 3. Development of Erythema ( $\geqq 1 \mathrm{~cm}$ ) in the Course of Three Days Following Vaccination of Students Aged 16-17 Years

\begin{tabular}{lllllllll}
\hline $\begin{array}{l}\text { Time } \\
\text { after } \\
\begin{array}{l}\text { vaecina- } \\
\text { tion } \\
\text { (hours) }\end{array}\end{array}$ & \multicolumn{2}{l}{\begin{tabular}{l}
$0.5 \mathrm{ml}$ vaccine subcutaneously \\
\cline { 2 - 8 }
\end{tabular}} & $\begin{array}{l}\text { Number of } \\
\text { vaccinees }\end{array}$ & $\begin{array}{l}\text { Occurrence } \\
\text { of erythema }\end{array}$ & $\begin{array}{l}\text { Mean size of } \\
\text { erythema } \\
\text { (cm) }\end{array}$ & $\begin{array}{l}\text { Number of } \\
\text { vaccinees }\end{array}$ & $\begin{array}{l}\text { Occurrence } \\
\text { of erythema }\end{array}$ & $\begin{array}{l}\text { Mean size of } \\
\text { erythema } \\
\text { (cm) }\end{array}$ \\
\hline 24 & 42 & 2 & $(5)^{2}$ & 1.5 & 43 & 17 & $(39)$ & 1.8 \\
48 & 42 & 5 & $(12)$ & 1.3 & 43 & 13 & $(30)$ & 1.8 \\
72 & 42 & 2 & $(5)$ & 1.3 & 43 & 3 & $(7)$ & 1.7 \\
\hline
\end{tabular}

1 The largest erythema observed: 2.5 and $3.5 \mathrm{~cm}$.

2 Numbers in parentheses: mean percent.

The frequency of axillary temperature elevation in these subjects is presented in Table 2. The temperatures reached a subfebrile level only, and their incidence was quite low. 
The development of erythema of $\geqq 1 \mathrm{~cm}$ in subjects aged $16-17$ years in the course of three days after vaccination is presented in Table 3 . The incidence of erythemas in subcutaneously vaccinated persons was highest after 48 hours and in intradermally vaccinated persons after 24 hours. The difference in the frequency of erythema in subcutaneously and intradermally vaccinated subjects is significant $(\mathrm{P}<0.05)$. It should be noted that the local reaction did not reach the size of $\geqq 4 \mathrm{~cm}$ in any of these subjects.

The frequency of elevated temperature in the same subjects and their nonvaccinated contacts is shown in Table 4 . It can be seen that the incidence of elevated temperature was almost identical in both groups during the first 48

Table 4. Increase of Temperature in the First 3 Days Following Vaccination in Students Aged 16-17 Years

\begin{tabular}{|c|c|c|c|c|c|}
\hline \multirow{3}{*}{$\begin{array}{l}\text { Time after } \\
\text { vaccination } \\
\text { (hours) }\end{array}$} & \multirow[t]{3}{*}{ Temperature } & \multirow{2}{*}{$\begin{array}{l}0.5 \mathrm{ml} \text { vaccine } \\
\text { subcutaneously }\end{array}$} & \multirow{2}{*}{$\begin{array}{l}0.1 \mathrm{ml} \text { vaccine } \\
\text { intradermally }\end{array}$} & \multicolumn{2}{|c|}{ non-vaccinated } \\
\hline & & & & $\begin{array}{l}\text { with } \\
\text { temperature }\end{array}$ & $\begin{array}{l}\text { without }{ }^{1} \\
\text { temperature }\end{array}$ \\
\hline & & $43^{2}$ & 42 & 29 & 47 \\
\hline & $37.0-37.9$ & $11^{3} \quad(26)^{4}$ & $13(31)$ & $15(52)$ & $9(19)$ \\
\hline \multirow[t]{3}{*}{24} & $38.0-38.9$ & $2(5)$ & - & - & - \\
\hline & $39.0-40.0$ & - & - & - & - \\
\hline & $37.0-37.9$ & $12(28)$ & $13(31)$ & $13(45)$ & $14(30)$ \\
\hline \multirow[t]{3}{*}{48} & $38.0-38.9$ & - & - & $1(4)$ & - \\
\hline & $39.0-40.0$ & $1(2)$ & - & - & - \\
\hline & $37.0-37.9$ & $8(18)$ & $11(26)$ & $10(34)$ & $7(15)$ \\
\hline \multirow[t]{2}{*}{72} & $38.0-38.9$ & - & $1(2)$ & $1 \quad(3)$ & - \\
\hline & $39.0-40.0$ & - & - & - & - \\
\hline
\end{tabular}

I On the day of vaccination

2 Number of Children in group

3 Including temperatures prolonged over 1 day

4 Numbers in parentheses: mean percent

hours. At 24 hours, a temperature increase was more frequent in both subcutaneously and intradermally vaccinated subjects than in their non-vaccinated healthy schoolmates; none of these differences was significant $(P>0.05)$. Temperature increase was less frequent in vaccinees than in non-vaccinated subjects having elevated temperature on the day of vaccination. This difference was significant $(\mathrm{P}<0.05)$.

\subsection{Serological Studies}

The results obtained in HIT and strain-specific CFT are summarized in table 5. Because the differences found between the antibody responses after subcutaneous and intradermal vaccination were not significant $(P>0.05)$, the data from all subjects in each age group were combined.

It can be seen that in the youngest age group the $\mathrm{HI}$ antibody response was limited to the $\mathrm{A}_{2} /$ Taiwan and B/Md viruses, against which the majority of subjects 
possessed antibody prior to vaccine administration. In addition, three subjects developed antibody reactive with the $\mathrm{B} /$ Lee virus. In the group aged $16-17$ years the pattern of $\mathrm{HI}$ antibody response was broader. In most of the subjects the vaccination resulted in an antibody response not only to the $A_{2}$ and $B / M d$ viruses, but also the $\mathrm{AA}$ and $\mathrm{B} /$ Lee viruses, to which some subjects possessed prevaccina-

Table 5. Antibody Response in Subjects Vaccinated with Polyvalent Hemagglutinin Vaccine as Determined by Hemagglutination Inhibition (HI) and Strain-Specific Complement Fixation (CF) Tests

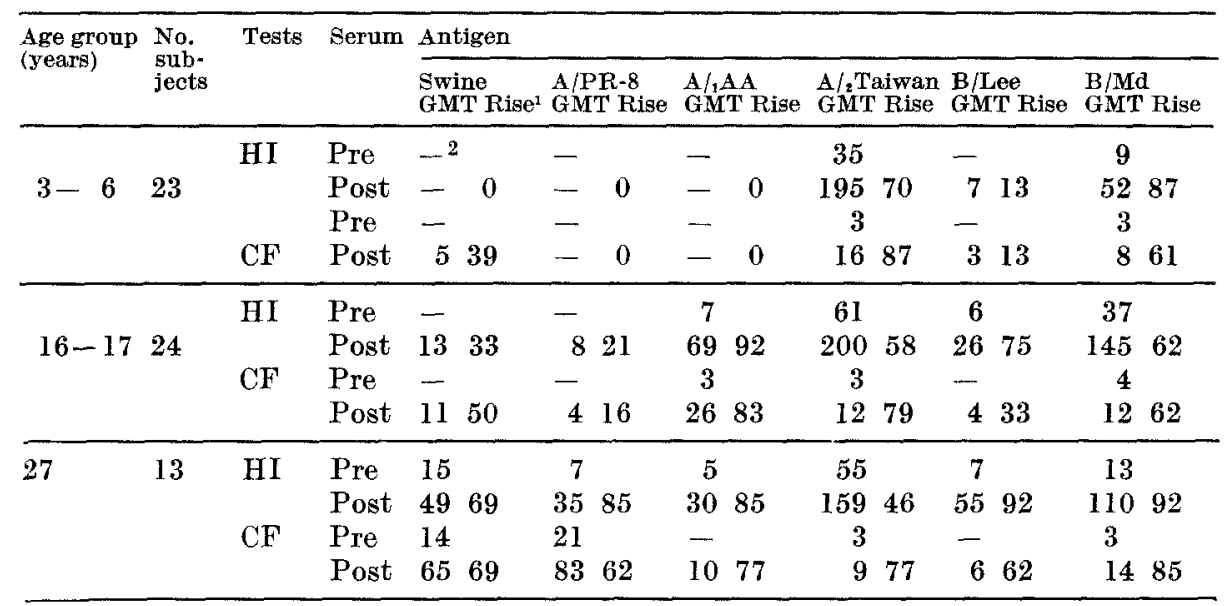

1 Percent of subjects with seroconversion from negativity to positivity or who developed fourfold or greater increase of titre

2 Antibodies were not detected in any serum tested

tion antibody. In a few subjects an antibody rise to Swine and A/PR 8 viruses was also detected. In the group of laboratory personnel (aged 27 years or more), which had the highest level of prevaccination immunity, a good antibody response was detested to all six viruses.

The antibody response pattern in CFT was in most instances similar to the results of HIT. This applies not only to the groups, as it is apparent from the table, but to individual subjects as well. The GMTs of CF antibodies were lower than those of HI antibodies, with the exception of the Swine and PR 8 antibodies in the oldest age group. In this age group prevaccination antibodies to these two viruses were detected at a higher frequency in CFT than in HIT. It can be seen that the prevaccination GMT of PR 8 antibody was higher in CFT than in HIT, and the GMT of Swine antibody was equal in both tests. This was not observed in either of the other groups with any of the viruses.

Antibody rises were sometimes more frequent in HIT, sometimes in CFT. The most marked difference in favour of the HI test was observed with the B/Lee virus; e.g., in the group of subjects aged 16-17 antibody rises to this virus were detected twice as frequently by HIT as by CFT. On the other hand, antibody rises to the Swine virus were detected more frequently by CFT than by HIT. This difference was most striking in the youngest age group, where nearly $40 \%$ of subjects developed antibody detectable by CFT but none developed antibody 
reactive in HIT. To investigate this interesting discrepancy, the sera from these subjects were examined once more in HIT using both intact Swine virus and the $V$-Swine antigen as hemagglutinin. Six serum pairs were available for this investigation. The results are shown in Table 6 . It can be seen that in all six subjects, HI antibodies were detected when using the antigen from disrupted virus, while the tests with intact virus were negative.

Table 6. Hemagglutination-Inhibition Antibody in Paired Sera of Subjects Aged 3--6 years, Using Intact Swine Virus and Swine $V$ Antigen as Hemagglutinin

\begin{tabular}{lllr}
\hline Subject & Serum & \multicolumn{2}{c}{ Antibody Titre } \\
\cline { 2 - 4 } & & Intact Swine & $\nabla$-Swine \\
\hline 1 & Pre & $<10$ & $<10$ \\
& Post & $<10$ & 40 \\
\hline 2 & Pre & $<10$ & $<10$ \\
& Post & $<10$ & 20 \\
\hline 3 & Pre & $<10$ & $<10$ \\
& Post & $<10$ & 40 \\
\hline 4 & Pre & $<10$ & $<10$ \\
& Post & $<10$ & 40 \\
\hline 5 & Pre & $<10$ & $<10$ \\
& Post & $<10$ & 40 \\
\hline 6 & Pre & $<10$ & $<10$ \\
& Post & $<10$ & 80 \\
\hline
\end{tabular}

1 Reciprocal of the highest serum dilution giving positive reaction.

In addition, sera from all three groups of vaccinees were tested for antibodies to the $\mathrm{S}$ antigens of influenza $\mathrm{A}$ and $\mathrm{B}$. The results are presented in Table 7 . It can be seen that antibody rises to both antigens were frequently detected in all three age groups. With influenza A S-antigen, the frequency of antibody responses

Table 7. Antibody Response in Subjects Vaccinated with Polyvalent Hemagglutinin Vaccine as Determined in Type-Specific Complement-Fixation Test

\begin{tabular}{|c|c|c|c|c|c|c|}
\hline \multirow{2}{*}{$\begin{array}{l}\text { Age group } \\
\text { (years) }\end{array}$} & \multirow[t]{2}{*}{ No. subjects } & \multirow[t]{2}{*}{ Serum } & \multicolumn{4}{|c|}{ Antigen } \\
\hline & & & $\begin{array}{l}\text { S-A } \\
\text { GMT }\end{array}$ & Rise $^{1}$ & $\begin{array}{l}\text { S-B } \\
\text { GMT }\end{array}$ & Rise \\
\hline \multirow[t]{2}{*}{$3-6$} & 23 & Pre & $--^{2}$ & & - & \\
\hline & & Post & 12 & 86 & 7 & 56 \\
\hline \multirow[t]{2}{*}{$16-17$} & 24 & Pre & 5 & & 5 & \\
\hline & & Post & 14 & 50 & 9 & 29 \\
\hline \multirow[t]{2}{*}{27} & 13 & Pre & 11 & & 4 & \\
\hline & & Post & 29 & 38 & 12 & 77 \\
\hline
\end{tabular}

1 Percent of subjects who developed fourfold or greater increase of titre.

2 Antibodies were not detected in any serum tested. 
decreased with age. This was not true for the influenza B S-antigen; there antibody rises were most frequent in the oldest group of subjects. To confirm that the substance detected by CFT was really $\mathrm{S}$-antibody, several paired sera were also examined by the immunofluorescence technique using rhesus monkey-kidney cells infected with the $A_{2}$ /Singapore MK virus. The results in two serum pairs are

\begin{tabular}{|c|c|c|c|}
\hline Subject & Serum & $\begin{array}{l}\text { CF-S Anti- } \\
\text { body titre }\end{array}$ & $\begin{array}{l}\text { Intranuclear } \\
\text { fluorescence in } A_{2-} \\
\text { infected RMK cells }\end{array}$ \\
\hline 7 & $\begin{array}{l}\text { Pre } \\
\text { Post }\end{array}$ & $<\begin{array}{r}\mathbf{5} \\
80\end{array}$ & $\begin{array}{l}0 \\
+++\end{array}$ \\
\hline 8 & $\begin{array}{l}\text { Pre } \\
\text { Post }\end{array}$ & $<\begin{array}{r}5 \\
80\end{array}$ & $\begin{array}{l}0 \\
++t\end{array}$ \\
\hline $\begin{array}{l}\text { Control } \\
\text { guinea } \\
\text { pig sera }\end{array}$ & $\begin{array}{l}\text { Negative } \\
\text { Anti S-A }\end{array}$ & $<\begin{array}{r}5 \\
160\end{array}$ & $\begin{array}{l}0 \\
++++\end{array}$ \\
\hline
\end{tabular}

1 All sera diluted $1: 2 ;+$ to ++++ refer to the intensity of fluorescence; RMK $=$ rhesus monkey kidney.

shown in Table 8. Prevaccination sera negative for S-antibody in CFR did not react with intranuclearly localized S-antigen. Post-vaccination sera possessing anti-S antibody detectable by CFT also gave a positive reaction with the S-antigen in the immunofluorescence test.

\section{Discussion}

The systematic follow-up of clinical reactions after the administration of the polyvalent hemagglutinin influenza vaccine revealed a very low reactogenicity of the vaccine in the two age groups ( $3-6$ and $16-17$ years) studied. The differences in the frequency and severity of local reactions after subcutaneous and intradermal vaccination found in each group and between the two groups are not well understood. They may be associated with the different amount of vaccine administered, differences in vaccine resorption and age-dependent differences in skin elasticity.

The serological data obtained confirm previous findings, indicating that the administration of the hemagglutinin influenza virus vaccine induces an HI antibody response in human beings (Davenport et al., 1964; HenNeSSY and DavenPORT, 1967; BraNdom et al., 1967). In addition to HIT, the strain-specific and typespecific CFT were also used in the present study. The CFT with the $V$ antigens of influenza viruses had been used for studying the antibody response to a monovalent inactivated $A_{2}$ vaccine by Hobson and Pearson (1961) and Lief and Henle (1960). The former group compared the antibody response in HIT and strain-specific CFT in individuals who had experienced natural infection with $A_{2}$ virus with those who had received one dose of inactivated vaccine. In the 
maturally infected subjects they obtained a narrow antibody response in HIT but a broad antigenic reaction in CF with various $\mathrm{V}$ antigens including such distant strains as Swine or A/WS. In the vaccinated subjects, both ther HI and the CF antibody responses were narrow. LIEF and HENLe, who studied the $V$ antibody response after administering a similar vaccine, rarely found antibodies to heterologous strains, unless these antibodies were present in the preimmunization sera; antibodies to Swine were the exception. Thus far, the strain-specific CF test has not yet been employed in studying the antibody response to hemagglutinin influenza vaccinees. The results obtained in the present study with the strainspecific CFT correspond in principle with the results of HIT. Both the incidence and titres of CFV antibodies alike in pre-vaccination and post-vaccination sera were lower than in HIT. These difference may be associated partly with the lower sensitivity of the CFT; the absence of CF antibody in some post-vaccination sera may also be due to the timing of the second bleeding.

One exception to this general pattern was seen in the development of Swine CF-V antibody in nearly forty per cent of subjects aged $3-6$ years; none of them developed HI antibody to Swine virus. However, when ether-extracted $V$ antigen was used instead of intact virus as hemagglutinin, seroconversion from negative to positive was observed in all the six subjects investigated. Two explanations might be proposed : 1) that ether treatment made the hemagglutinin more susceptible for deter-mining low levels of antibody (BERLIN et al., 1963);2) that in the vaccine and in the $V$ antigen preparation used in the serological tests, an antigen (or antigens) was present which was absent at the surface of the intact Swine virions, and that this new antigenic activity was carried by at least a high proportion of the virus fragments responsible for the hemagglutination (DAVENPORT et al., 1964). With the present evidence a decision in favour of one of these possibilities cannot be made. Another interesting discrepancy between the results of CFT and HIT was found in the PR 8 antibody status of the oldest group; in both pre- and post-vaccination sera the incidence and titres of CF antibodies were higher than those of HI antibodies. The nature of this difference is not clear, and may be related to the rather small number of subjects tested. When interpreting the results of CF test with $\mathrm{V}$ antigen the possibility should be also considered that anti-neuraminidase antibody could play some role in the results obtained. It has been shown that neuraminidase is present in ether split virus preparation (NeURATH and RUBIN, 1969) and that anti-neuraminidase antibody can be detected in CF test (WEBSTER and Pereira, 1968; Laver and Kilbourne, 1966).

An early experience was that type-specific (S) antibody did not develop after administering inactivated influenza vaccine (e.g. WIENER et al., 1946), although its development was reported after the use of highly potent vaccine (MCDoraLD and ANDrEws, 1955). In the present series of experiments, an $S$ antibody response was obtained in most of the subjects. In spite of the high degree of specificity of the reagents used (see Materials and Methods), it is possible that at least in some individuals the highly avid human sera picked up trace amounts of $\mathrm{V}$ antigen present in the $\mathrm{S}$ antigen preparations that were not detected with the less avid guinea-pig anti-V sera. However, the results of immunofluorescence tests indicate that in other subjects the rise of $\mathbf{S}$ antibody really did occur, being most likely conditioned by the presence of free $S$ antigens in the vaccine preparation. These 
results suggest that CF-S tests would scarcely be of decisive value in distinguishing between vaccine responses and natural influenza virus infection in recently vaccinated subjects.

\section{References}

1. Berlin, B. S., J. L. MCQueen, E. Minuse, and F. M. Davenport: A method for increasing the sensitivity of the hemagglutination-inhibition test with equine influenza virus. Virology 21, 665-666 (1963).

2. Brandon, F. B., F. Cox, G. O. Lease, E. A. Trmm, E. Quinn, and I. W. McLean: Respiratory virus vaccines. III. Some biological properties of sephadex-purified ether-extracted influenza virus antigens. J. Immunol. 98, 800-805 (1967).

3. Davenport, F. M., A. V. Hennessy, F. B. Brandon, R. G. Webster, C. D. BARret, and O. G. LEasE. Comparison of serologic and febrile responses in humans to vaccination with influenza A viruses or their hemagglutinins. L. Lab. clin. Med. 63, 5-13(1964).

4. Davenport, F. M., A. V. Hennessy, J. Drescher, and R. G. Webeter: Analytical, serological and clinical experiences with the hemagglutinating subunits of influenza A virus. In Ciba Symposium of Cellular Biology of Myxovirus Infectious, pp. 272-287, Boston: Little, Brown and Co., 1964.

5. Davenport, F. M., and E. Minuse: Influenza viruses. In: Diagnostic Procedures for Viral and Rickettsial Diseases. Amer. publ. Hlth Ass. pp. 455-469 (1964).

6. HenNessy, A. V., and F. M. DAvenPoRT: Vaccination of infants against influenza with polyvelant influenza hemagglutinin. J. Amer. med. Ass. 200, 896-898 (1967).

7. Hobson, D., and E. PeArson: Serological responses to Asian influenza viruses in men: a comparison of hemagglutination-inhibition and complement-fixation methods. Brit. J. exp. Path. 42, 53-62 (1961).

8. Laver, W. G., and E. D. KILBoURNe: Identification in a recombinant influenza virus of structural proteins derived from both parents. Virology 30, 493-501 (1966).

9. Lief, F. S., and W. Henle: Antigenic analysis of influenza virus by complement fixation. VI. Implications of age distribution of antibodies to heterologous strains following infection and vaccination. J. Immunol. 85, 494-510 (1960).

10. McDonald, J. C., and B. E. Andrews: Diagnostic methods in an influenza vaccine trial. Brit. med. J. II, $1232-1235$ (1955).

11. Neurath, A. R., B. A. Rubin, and R. W. Hartzell: Release of neuraminidase from hemagglutinin caused by treatment of influenza virus with ether. Arch. ges. Virusforsch. 28, $421-423$ (1969).

12. Tučková, E., V. Vonka, and M. StáreK: Comparison of genetic properties of influenza viruses before and after repeated passages in monkey-kidney cell culture. Acta virol. 12, 316-323 (1968).

13. Vonka, V.: Plaque technique with an influenza A-2 virus in rubber stoppered bottle cultures from monkey kidney cells. Arch. ges. Virusforsch. 15, 514-524 (1965).

14. Webster, R. G., and H. G. Pereira: A common surface antigen in influenza virus from human and avian solurees. J. gen. Virol. 3, 201-208 (1968).

15. Wiener, M., W. Hente, and G. Henle: Studies on the complement-fixation antigens of influenza viruses types A and B. J. exp. Med. 83, 259-279 (1946).

16. ZÁvadová, H., L. KUTINOVÁ, and V. VonKA: P'reparation of antisera against the $S$ antigen of influenza $A$ virus by immunization of guinea pigs with internal $S$ antigen. Arch. ges. Virusforsch. 20, 421-429 (1967).

17. Závadová, H., V. Vonka, L. Kutinová, and E. TUČKová: Complete and abortive infection of cell cultures by influenza A-2 virus. J. gen. Virol. 2, $341-346$ (1968).

Author's' address: Hana Závadová, Department of Experimental Virology, Institute of Sera and Vaccines, Šrobárova 48, Prague 10, Czechoslovakia. 